\title{
The Idea of World Domination \\ in the Public Consciousness in Europe in the Early and Developed Middle Ages
}

\author{
Andrei V. Zberovskii \\ and Marina N. Kriuk* \\ Krasnoyarsk State Pedagogical University \\ named after V.P. Astafiev \\ 89 Ady Lebedeva Str., Krasnoyarsk, 660049, Russia
}

Received 12.04.2016, received in revised form 22.06.2016, accepted 15.07.2016

The article explores a public thought and public consciousness in the early and developed Middle Ages in Europe. It reveals the presence of the idea of world domination in the public mind of medieval Europe. The article also discusses the specificity of the idea of world hegemony in the public consciousness in the studied period. It explains the change of the idea of world domination in comparison to the previous period (Ancient World). There are numerous examples of people pretending to the world domination. The author used historical sources, as well as works of the famous Russian and foreign researchers.

Keywords: Early and developed Middle Ages, medieval Europe, world domination, world empire, world hegemony, world sovereignty, public thought, public consciousness, Crusades, Attila, Charlemagne, Otto I, Otto II, Otto III, Gregory VII, Henry II, Frederick I, Frederick II, Richard the Lionheart, Philip II.

DOI: 10.17516/1997-1370-2016-9-9-2122-2130.

Research area: theory and history of culture.

\section{Introduction}

The ideas that originated in ancient times continue to develop in the Middle Ages, has a strong impact on people's minds, form a certain course of actions of the rulers and their subjects. In ancient times, a number of countries, including China (Kriuk, 2016), India (Kriuk, 2015), Egypt and the countries of Mesopotamia (Kriuk, 2014) carried out numerous attempts to establish global hegemony. Medieval Europe is just beginning the path of its development on the world stage, while Rome (Kriuk, 2015) has won many victories over the nations of the Ancient world, is trying to turn the idea of world domination into reality, to become the ruler of all nations. By the beginning of the Middle Ages the Western Roman empire will fall and the palm of victory will go into the hands of other countries. And the European states will be these countries that, in practice, based on the experience of the ancient states, will carry out

(c) Siberian Federal University. All rights reserved

* Corresponding author E-mail address: mari.kryuk@yandex.ru 
numerous attempts to usurp power in the whole world. The European States in the analyzed period were primarily agrarian, feudal relations were a frequent practice, subsistence farming dominated in that period, and commodity-money relations were poorly developed. The studied period, in contrast to the countries of the Ancient world, is characterized by an exceptionally strong role of the church and a high degree of ideologization of society. Christianity becomes a single religion and the basis for uniting Europeans and forming a single European civilization. By the middle of the Middle Ages the European states become the strongest in the known world, the process of European integration and the idea of the world hegemony to spread along with cultural and religious customs begins. In today's world, the European states are among the strongest in the world arena, most states try to get into the European Community, the processes unfolding in different regions of countries near and far abroad can directly affect safety of the peoples of the global space, which makes the world domination topic particularly relevant.

The purpose of this article is to explore a public thought ${ }^{1}$ and public consciousness ${ }^{2}$ of the Middle Ages relying primarily on written sources and literature and to identify the specifics of its existence in European countries in the present historical period.

Relevance of this problem is of scientific and practical significance.

The scientific significance lies in the fact that in modern literature there are almost no works, in which a public thought and public consciousness of the medieval Europe are analyzed in this context.

The scientific novelty of this work is to try to examine the studied issue as a complex taking into account its historical development in the light of the idea of world domination in the public consciousness.

\section{The practical significance of this work lies} in the possibility of using the work material to conduct training sessions on the selected topic.

Before we proceed to the analysis of literature on the subject let us reveal the meaning and content of the concept of public consciousness. Public consciousness determined the lives of people in many periods of time, and the era of the Middle Ages was not an exception.

A contemporary researcher Spirkin has defined and expressed the essence and content of public consciousness very precisely: "Public consciousness is the views of people on the phenomena of nature and social reality expressed in a natural or artificial language, works of spiritual culture, social norms and attitudes of social groups, people and humanity as a whole" (Spirkin, 2006).

Spirkin also defines the essence of public consciousness: "The essence of public consciousness is that it can make sense of social existence only under condition of the simultaneous active-creative transformation of it" (Spirkin, 2006).

It is noteworthy that the content of public consciousness includes “....a set of generalized concepts, ideas, theories, feelings, morals and traditions" (Spirkin, 2006), through the prism of which the idea of world domination came up.

We should note quite broad elaboration of the idea of world hegemony in national and foreign literature, but the studies are fragmented addressing a particular historical region. Problematics of world domination can be observed in the works of the following authors: V. Balakin (2004), M. Zaborov (1980) Zh. Kembaev (2012), A. Khriakov (2014), I. D’iakonov (1994), P. Antonetti, (2004), J. Chastenet (2004), S. Kaspe (1997).

The era of the Middle Ages inherited the ideas that emerged in the era of the Ancient world - one of these ideas is the idea of world 
domination, which will be widely distributed in the period of the Middle Ages.

Much have I heard of men who wield power!

Every prince must practice virtue,

Each nobleman guide his land like others,

If he wishes his princely throne to prosper.

For a time Hwala was the best of these,

And Alexander the most powerful of all

The race of men, and he prospered the most

Of all those I've heard of on the face of the earth.

(Smirnitskaya, Tikhomirov, 1982)

The imperial idea of Alexander the Great caused a positive response in the public consciousness of medieval Europe and found broad audience to turn it into reality, there is no dispute about the presence of the idea of world hegemony in the studied period.

Turning to the analysis of the studied literature on the subject it is logical to start with the question: who was the first to claim to sovereignty over the whole world?

Traditionally, history of the Middle Ages begins with 476 , with the fall of the Western Roman Empire, but we believe that it is appropriate to start with the Great Migration in the context of the studied problem. At the beginning of history of medieval Europe the Great Migration takes place. Attila $(434-453)^{3}-$ the ruler of the Huns created a huge power that stretched from the Volga to the Rhine. The image of the leader formed the basis of "The Song of the Nibelungs", and it has traditionally been considered that the personality of Attila is embodied in the image of Etzel - one of the heroes of this work. The might of Etzel is unlimited: in the Song Etzel is called "powerful" (Admoni, Zhirmunskii, Korneev, Sigal, 1972) and "lord" (Admoni, Zhirmunskii, Korneev, Sigal, 1972). Military superiority of
Etzel is obvious: "the lord of the Huns had a huge amount of battlers" (Admoni, Zhirmunskii, Korneev, Sigal, 1972) and had three dozen states.

And if you deign to wed my noble lord,

The power of twelve great crowns is your reward,

And you are free to rule three dozen countries that he conquered.

(Admoni, Zhirmunskii, Korneev, Sigal, 1972)

One of the first states founded in medieval Europe is the Frankish kingdom. The most important source on history of the Frankish State is the Salic law. We have analyzed the document, which drew us to the following conclusion: there is no mention of world domination, and the praise of the people of the Germanic tribes is very modest. "The Frankish people is nice, created by god, strong in arms, steadfast in a peace treaty, wise in advice, noble in body, undamaged in purity, excellent in posture, brave, quick and restless, converted to the Catholic faith, free from heresy" (Gratsianskii, 1950).

Most researchers agree that the first person to attempt to conquer the world was Charles the Great (768-814). A. Khriakov analyzed numerous materials on the life of Charlemagne and drew attention to the following fact: "Eastern policy of Charles the Great, like all his undertakings, was rooted in the Christian imperial idea" (Khriakov, 2014). D'iakonov and Antonetti believe that Charles the Great tried to recreate the Western Roman Empire, but Balakin adheres to a completely opposite point of view considering that the state created by Charlemagne is neither reflection nor continuation of the Western Roman Empire.

After analyzing literature on the subject we can conclude the following: Charlemagne was not the first person who started to carry out imperial 
policy in medieval Europe, although there are numerous references in historical sources about his desire to take over the world.

In the early Middle Ages, Otto I (936-973) founded the Holy Roman Empire in order to create a world state. "The empire created by Otto I was perceived by contemporaries as the fulfilment of hopes associated with the imperial idea, which continued to live after the collapse of the Western Roman Empire" (Balakin, 2004).

Otto II (961-983) and Otto III (983-1002) continue to follow and implement the imperial policy of their predecessor, and examples of its implementation will become paradigmatic. Otto III sought to revive the Roman Empire in the past greatness, dreamed of creating a single world Christian power with the centre in Rome and Aachen, and probably in Constantinople. The era of the Crusades that lasted from the late $11^{\text {th }}$ to the last third of the $13^{\text {th }}$ century became the quintessence of the idea of world domination.

Describing the era of the Crusades it is impossible not to note the work by M. Zaborov "Crusaders in the East", in which the scientist describes the reality of the $11^{\text {th }}$ century, highlights the chronological framework and the motives of the Crusades, lists persons seeking to create a "universal monarchy".

M. Zaborov notes the following motives:

- desire to buy luxury goods in the East;

- "the landless" and "the poor" sought to improve their position outside the sea, and at the same time to atone for the sins committed at home;

- persistent desire of feudal lords to acquire land;

- dominance at sea.

The above-mentioned motives are quite traditional for military marches both for the era of the Ancient world and the Middle Ages, but along with these motives Zaborov adds another motive - claim to supremacy over the whole world - "A desire of Gregory VII (1073-1085) to implement a theocratic program "to create a universal monarchy headed by the papacy and to force the Christian kings to oath to the apostolic throne" (Zaborov, 1980).

In the $12^{\text {th }}-13^{\text {th }}$ centuries, Crusades were supported by the Church, moreover, they were approved by it and surrounded by the halo of the holy martyrdom, and the secular authorities also contributed to the Crusades. G. Brunel-Lobrichon and C. Duhamel-Amado in their study (Everyday life in the time of troubadours. The $12^{\text {th }}-13^{\text {th }}$ centuries) analyze the life of poets paying attention to the following fact: "When taking service of the lord, troubadours have to support their patrons in all their feuds" (Brunel-Lobrichon and DuhamelAmado, 2003), which becomes an unwritten duty of a vassal to his lord.

Troubadours glorify their lords attributing many great deeds to them and mention of the aspirations of kings to dominion over the whole world.

If I were a mighty king,

The whole world would be yours.

But I will bring your name into repute,

Right to the Far East.

(Brunel-Lobrichon and Duhamel-Amado, 2003)

The researchers mentioned above point out numerous works of poetry of the troubadours that reflect the public consciousness of the $12^{\text {th }}$ $13^{\text {th }}$ centuries, where the presence of world domination in the minds of masses can be traced very clearly. Here is one of the examples:

The successor of Roland affairs

Was zealous

At war like an eagle,

Fearless in battle,

The whole world was brought 
In amazement by giant

From the Nile to the countries,

Which border with ocean.

(Brunel-Lobrichon and Duhamel-Amado,

In his study Zaborov lists persons claiming to the world domination, including Henry II (1154-1189), Frederick I (1152-1190), Frederick II (1197-1212), Richard the Lionheart (1189-1199), Philip II (1179-1223) (Zaborov, 1980).

The Crusades continue in the $13^{\text {th }}$ century, one of the famous campaigns of the period is the Albigensian Crusade initiated by Pope Innocent III (1198-1223). "The Song of the Albigensian Crusade" in this source still glorifies the church power and the Pope.

His Holiness the Pope! You are a stronghold keeping us from evil,

The Holy See gives you the great rights.

(Belavin, Morozova, 2011)

A famous Italian politician and a poet Dante Alighieri (1265-1301) declares in favor of the idea of a secular universal monarchy: "Italy would have been a garden, Rome - a spiritual capital, the Pope, the personification of one of the two universal powers, would have taken care of the spiritual salvation of mankind, and the Emperor would have led it along the path of earthly prosperity" (Antonetti, 2004).

The ideas that were put forward by Dante Alighieri about arrangement of the world state are considered in the monograph by Zh. Kembaev who comes to the following conclusion: "for Dante such arrangement certainly was a comprehensive universal state, namely, the revived Roman Empire" (Kembaev, 2012).

The idea of creating a universal monarchy is haunted by thinkers of the next generation. A successor of Dante, Pierre Dubois (1255 - 1323), moves the centre of the world from Italy to France: "for the world it would have been better if it obeyed France, because the French are better than any other nations, and they know how to wisely handle the power" (Kembaev, 2012).

Italy will not be able to forget the glory that it has been surrounded by in the era of the Ancient world, and the Italians could feel this glory in full putting into practice the idea of world domination after the capture of Rome by the barbarians and the destruction of the Western Roman Empire. This idea will be in the minds of the Italians in the subsequent generations, but this idea will take a new guise. S. Kaspe in his study devoted to the empire highlights its signs: "the empire is characteristic of a desire for the unlimited hegemony" (Kaspe, 1997). The researcher also considers the issue of conditions of formation of empires, and one of such conditions is a sacred nature of power of the ruler. A functional analysis of the imperial systems includes expansion that is supported by "a claim to the imperial universal sovereignty" (Kaspe, 1997). In the Ancient times, nobody could doubt the sacred power of the Roman emperor, his power was unlimited, but in the Middle Ages the power of the pope has got a sacred nature. Alexander VI from the Borgia family takes up a post of the pope, and while serving as pope (since 1492-1503) his power is unlimited, and the people during a festive procession will carry a banner saying "Rome was ascended by Caesar, now it is greater under the sceptre of Alexander, Caesar was a man, but Alexander is a god" (Chastenet, 2004). Alexander VI has had a huge impact on the entire course of Italian history, moreover "to some extent he considered himself the heir of Augustus and dreamed of becoming a Master of the world" (Chastenet, 2004).

The debate around the literary and political heritage of the great Florentine, Niccolo Machiavelli, continues for a long time. Reflections 
of Machiavelli are most fully expressed in two treatises "The Prince" and "Florentine Histories". We should not oppose these two works, in which the author explores the forms and methods of political organization of society. "The Prince" and "Florentine Histories" complement each other well, although it is not coincidental that "The Prince" attracts the attention of the followers of the Machiavelli's creative work.

In the political treatise, Machiavelli describes Florence complaining about the decline in the country and the fact that the rulers do not have the desire for true glory: "and so it happened that in the whole world, especially in Italy, many areas turned out to be deserted compared to the Ancient times. And all this was and still is a consequence of the fact that the rulers do not have the desire for true glory, and the republics do not have commendable orders" (Machiavelli, 1973).

A perfect image, but not the image of the perfect ruler. Creating the image of the ruler, Machiavelli sets himself two tasks - to set Italy free from the foreign domination and then unite it. The immediate objective of the Emperor is liberation of Italy, while uniting the country is more a dream, fulfilment of which Machiavelli is afraid of and do not even dare to hope for (Machiavelli, 2013).

In his work Niccolo Machiavelli creates the best image of the ruler that, in his opinion, modern Italy needs (Machiavelli, 2013). The ruler does not aspire to world domination, he does not claim to power over the world like Sargon of Akkad $\left(24^{\text {th }}-23^{\text {rd }}\right.$ centuries BC) or Tuthmosis I (1504-1492 BC). The Machiavelli's Emperor is a civilized hero destined to transform contemporary Italy. Italy is united and indivisible. Machiavelli accurately thought through the creation of the new state, but it still remains a theory that failed to be realized in practice, the $16^{\text {th }}$ century could not offer a worthy candidate. The attempts to nominate world leaders also proved fruitless in all the subsequent centuries. The $19^{\text {th }}$ century fulfilled Machiavelli's dream, the world never saw the ruler. The image of the ruler created by the talent of Machiavelli is a mythical hero who cannot find a place in the real world.

\section{Conclusion}

\section{All of the above-said allows us to draw the} following conclusions:

The states of the early and developed Middle Ages in practice show their unequal opportunities of implementing the world domination ideas.

The idea of the world hegemony in medieval Europe firmly entrenched in the public consciousness and possessed the minds of prominent public and political figures. By the middle of the Middle Ages the European states become the strongest in the known world, begin the process of European integration, and follow the idea of world hegemony to spread along with cultural and religious customs. The idea of world domination inherited from the Ancient times gradually starts to evolve in the Middle Ages - the Emperor (representative of the secular power) will deal with claims of the papacy (representatives of the ecclesiastical authority) to rule in the established Christian world, since Christianity in the analyzed period of time becomes a universal religion capable of uniting all humanity into a single Christian empire. The idea of uniting all peoples in the Roman Empire turned into the idea of uniting all mankind into the Christian empire, Christianity will play a role of the general connecting factor. Rome ceases to be the only possible centre of the world, there will be new cities pretending to become a global centre. Apogee of the desire to create the world states is reached at the end of the $12^{\text {th }}$ - beginning of the $13^{\text {th }}$ centuries and is associated with the era of the Crusades. The states more and more specifically learn about the real dimensions of the global space, become aware of the scale of 
expansion required to fulfil this idea. The list of persons who claim to world dominance is growing, and the era of the Middle Ages does not end the attempts to turn the idea into reality, the policy of world hegemony is being implemented right up to the present day, only in other ways.

\footnotetext{
Under the public thought we understand the thought of leaders, well-known figures, scientists, philosophers, poets and researchers.

Under the public consciousness we understand the collective perceptions.

years in power
}

\section{References}

Admoni, V. G., Zhirmunskii, V. M., Korneev Iu.V., Sigal N.A. (1972). Pesn' o Nibelungakh [The song of the Nibelungs]. Leningrad, Science Publ., 144-157.

Antonetti, P. (2004). Povsednevnaia zhizh' Florentsii vo vremena Dante [Everyday life of Florence in the time of Dante]. Moscow, Molodaia Gvardiia Publ., 25.

Balakin V. (2004). Tvortsy Sviashchennoi Rimskoi imperii [The creators of the Holy Roman Empire]. Moscow, Molodaia Gvardiia Publ., 1.

Belavin I.O., Morozova E.V. (2001). Pesn' o krestovom pokhode protiv Al'bigoitsev [The song of the crusade against the Albigensians]. Moscow, Science Publ., 104.

Brunel-Lobrichon, G., Duhamel-Amado. C. (2003). Povsednevnaia zhizh'vo vremena trubadurov. $X I I-X I I I$ veka [Everyday life in the times of the troubadours. $12^{\text {th }}-13^{\text {th }}$ centuries]. Moscow, Molodaia Gvardiia Publ., 67-343.

Chastenet, J. (2004). Lukretsiia Bordzha [Lucrezia Borgia]. Moscow, Molodaia Gvardiia Publ., 49.

D'iakonov, I.M. (2007). Puti istorii. Ot drevneishego cheloveka do nashikh dnei [The path of history. From ancient man to our days]. Moscow, Komkniga Publ., 47.

Gratsianskii, N.P. (1950). Salicheskaia Pravda [Salic law]. Moscow, Moscow state pedagogical Institute named after V.I. Lenin Publ., 86.

Kaspe, S.I. (1997). Empire: Genesis, structure, functions. Polis. Political studies (5), 31-48.

Kembaev, Zh.M. (2012). Politiko-pravovaia istoriia idei edinoi Evropy: s drevneichikh vremen do sovremennosti [Political and legal history of the idea of a united Europe: from ancient times to the present]. Almaty-Astana, Academpress Publ., 44-54.

Khriakov, A.V. (2014). Charlemagne or "exterminator of the Saxons"? The struggle for the Frankish Emperor in Nazi Germany. People and texts. A historical anthology. (6), 325- 349.

Kriuk, M.N. (2014). No ideas of world domination in the public mind of Ancient Greece as a social and philosophical phenomenon [Otsutsvie idei mirovogo gospodstva $\mathrm{v}$ obshchestvennom soznanii Antichnoi Gretsii kak sotsial'no- filosofskii fenomen]. Materialy Vserossiiskoi nauchnoi konferentsii "Sovremennaia nauka: tendentsii i perspektivy razvitiia" [Proceedings of the All-Russian scientific conference "Modern science: tendencies and prospects of development"], Stavropol: North-Caucasus Federal University, 168-179.

Kriuk, M.N. (2014). The idea of world domination in the public consciousness in the countries of the Ancient East [Ideia mirovogo gospodstva v obshchestvennom soznanii stran drevnego Vostoka]. Sbornik statei XII Mezhdunarodnoi nauchno -prakticheskoi konferentsii 'Kul'tura. Dukhovnost'. Onshchestvo [Culture. Spirituality. Society: collection of materials of the International scientificpractical conference], Novosibirsk, The Center for Development of Scientific Cooperation, 51-58. 
Kriuk, M.N. (2015). The idea of world domination in the public consciousness in Ancient Rome [Ideia mirovogo gospodstva v obshchestvennom soznanii Drevnego Rima]. In Teoriia $i$ praktika nauki tert'ego tysiacheletiia [Theory and practice of science of the third Millennium], Ufa, Aeterna, 76-80.

Kriuk, M.N. (2016). The idea of world domination in the public consciousness in Ancient China [Ideia mirovogo gospodstva v obshchestvennom soznanii Drevnego Kitaia]. Sbornik statei IX Vserossiiskoi nauchnoi konferentsii Istoriia mirovykh tsivilizatsii: vospriiatie, obraz, predstavlenie vlasti [History of world civilizations: perception, image, representation of power: materials of the Ninth all-Russian scientific conference], Krasnoyarsk, Krasnoyarsk state pedagogical University named after V.P. Astaf'ev, 62-70.

Kriuk, M.N. (2015). The idea of world domination in the public consciousness in Ancient India [Ideia mirovogo gospodstva v obshchestvennom soznanii Drevnei Indii]. Sbornik statei Mezhdunarodnoi nauchno-prakticheskoi konferentsii Sovremennaia naukaL teoreticheskii i prakticheskii vzgliad [Modern science: theoretical and practical view, collection of materials of the International scientificpractical conference], Ufa, Aeterna, 75-79.

Machiavelli, N. (2013). Gosudar' [The Prince]. Moscow, Folio Publ., 397.

Machiavelli, N. Istoriia Florentsii [The history of Florence]. Moscow, Science Publ., 1973, 51.

Smirnitskaia, O.A., Tikhomirov, V.G. (1973). Drevneangliiskaia poeziia [Old English poetry]. Moscow, Science Publ., 15.

Spirkin, A.G. (2006). Filosofiia [Philosophy]. Moscow, Science, Gardariki, 637 - 639.

Zaborov, M.A. (1980). Krestonostsy na Vostoke [The crusaders in the East]. Moscow, Science Publ., 24.

\title{
Идея мирового господства
}

в общественном сознании Европы

в раннем и развитом Средневековье

\author{
А.В. Зберовский, М.Н. Крюк \\ Красноярский государственный педагогический \\ университет им. В.П. Астафьева \\ Россия, 660049, Красноярск, ул. Ады Лебедевой, 89
}

В статье исследуется общественная мысль и общественное сознание эпохи раннего и развитого Средневековья в странах Европы. Вылявено наличие идеи мирового господства в общественном сознании средневековой Европы. Показана специфика бытования идеи мировой гегемонии в общественном сознании в исследуемый период. В статье рассматривается изменение идеи мирового владычества по сравнению с предшествующим периодом (Древний мир). Приведены многочисленные примеры лии, претендовавщих на мировое господство. Автор при написании данной статьи использовал исторические источники, а также труды известных российских и зарубежных исследователей.

Ключевые слова: раннее и развитое Средневековье, средневековая Европа, мировое господство, мировая империя, мировая гегемония, мировое владычество, общественная мысль, 
общественное сознание, крестовые походы, Аттила, Карл Великий, Оттон I, Оттон II, Оттон III, Григорий VII, Генрих II, Фридрих I, Фридрих II, Ричард Львиное Сердие, Филипп II. Научная специальность: 24.00.01 - теория и история культуры. 